DOI https://doi.org/10.18551/rjoas.2017-01.17

\title{
SEVERAL FACTORS THAT INFLUENCE HOUSEHOLD ECONOMIC DECISIONS OF RICE FARMERS IN INDONESIA
}

\author{
Leki Silverius \\ University of Nusa Cendana, Penfui, Indonesia \\ E-mail: sil leki@yahoo.co.id
}

\begin{abstract}
The objective of this study is to point out the factors that influence household economic decisions in the use of labor, production, and consumption. This study was undertaken in Kupang regency, East Nusa Tenggara with 114 samples of agricultural household. A specification of household economic model used a simultaneous equations system. Parameter estimation uses two-stage least squares (2SLS) method. The results showed that the act of using labor in a household for rice farming was significant influenced by agricultural wage rate, rice product price, household income, farming area, and the number of household member. While the use of wage-labor was significant influenced by wage rate, farming area, and the use of household (domestic) labor. The use of urea and SP-36 was affected by ratio of rice price to fertilizer, and farming area. Rice production was influenced by farming area, total number of labor used, and amount of fertilizer used. Rice consumption from farming was positively significant influenced by an amount of rice production produced and the number of household member. Rice consumption from purchase was negatively influenced by the number of rice production but positively influenced by the number of household member.
\end{abstract}

\section{KEY WORDS}

Econometric model, labor, production, consumption, farmer.

Rice is a grass which produces seeds to be used as a staple for most Indonesian. Rice demand in Indonesia tended to be increase from year to year (Nurasa and Purwoto, 2005; Irawan, 2005). During the period of 2008-2012, rice demand increased up to 4.14 percent (Trade Ministry, 2013). The demand increases was caused by population increases and a change in consumption pattern of community that initially have non-rice consumption pattern, then changed to be rice consumption (Leki, 2010). On the other hand, rice plant was also needed as a raw material for food industry and non-food industrial raw materials, such as cosmetics industry and chemical industry (Central Statistics agency/BPS, 2011).

If the supply of local rice could not meet the needs, so that in the future Indonesia will be more depending on importing rice from other countries. Therefore, Indonesia has to make an effort to increase rice production by increasing plants productivity and land extension. According to domestic trade policy center (2013), source of rice growth from productivity was $0.86 \%$ and growth of harvest area was 1.99 percent per year.

Rice working in Indonesia is dominated by home-based business. In 2013 there were 14.206.355 agricultural households that attempted to plant rice (BPS, 2013). Agricultural households have a dual role in producing rice for household consumption needs or to meet the needs of the entire population.

Household in producing production unit by combining goods of modal and raw materials along with outpouring of work and time to produce final goods. (Becker, 1965) Agricultural household in maximizing the advantages to face the obstacles of time allocation, production, and income. (Barnum and Square 1979; Singh, et al.1986) According to Barnum and Square (1979) the total of household time were allocated to combine goods production and leisure, as well as good time allocation on farm and/or off-farm (Chang et al, 2012) Ellis (1998) then stated that household has the freedom to work household (domestic) labor and to rent labor from outside household in the applicable wage rate. 
The allocation of labor was influenced by several variables, such as wage rate, product cost, income level, and household characteristic. In addition to labor input, household should require other production inputs such as seeds, urea fertilizer, SP-36 fertilizer and so on to carry out production activity. Bokhuseva and Hockman (2004) stated that one of the factors that influence production was technical inefficiency. Furthermore, Kumbakhar (2002) stated that agricultural production related to farmers managerial ability in managing production.

Model of agricultural household economic has attracted the attention of researchers for a long time. Hanani and Yonekure (2009); Fariyanti et al (2007), used model of household economic to analyze the act of household economic decision-making behavior of vegetable farmers. Rochani and Lolollo (2005); Dwiastuti (2008); Setiani (2015); Makki (2014); Leki et al (2016) used household economic model to analyse the decision of agricultural household of crops.

Those results showed that agricultural household has a dual role in decision-making of consumption and production. The production decision directly affects the amount of income that will be accepted and the income level affects the decision of household consumption. While the influence of consumption towards production shows the different behavior. The results of study conducted by Nuhfil and Yonekure found that household consumption expenditure significantly influenced the decision-making of vegetable farmers household. However, the result of study conducted by Leki et al (2016) showed that non-food expenditure to have not significant influence over the use of fertilizer for maize plant.

Based on the analysis above, so that it is important to conduct research aiming to point out factors that influence household economic decisions in using of labor, production, and consumption.

\section{MATERIAL AND METHODS OF RESEARCH}

Study Area. This study was undertaken in Kupang Regency, NTT, Indonesia. This location was chosen since it is one of rice production centers in NTT with 21.765 ha in area. Samples of household was randomly chosen, there were 114 households from household population in two sample villages.

Data Analysis Method. In this study was constructed an economic model of agricultural household in the form of simultaneous equations consisting of 7 structural equations and 3 identity equations as follows:

(1) $L W H=a_{10}+a_{11} W+a_{12} P Q R+a_{13} H I+a_{14} F A+a_{15} N H M+\mu_{1}$

(2) $L O H=a_{20}+a_{21} W+a_{22} F A+a_{23} L W H+a_{24} S H I+\mu_{2}$

(3) $\mathrm{LUT}=\mathrm{LWH}+\mathrm{LOH}$

(4) $F U R=a_{30}+a_{31}(P Q R / P U F)+a_{32} F A+a_{33} E N F+\mu_{3}$

(5) $\mathrm{FSP}=\mathrm{a}_{40}+\mathrm{a}_{41}(\mathrm{PQR} / P S F)+\mathrm{a}_{42} \mathrm{FA}+\mathrm{a}_{43} \mathrm{ENF}+\mu_{4}$

(6) $\mathrm{QR}=\mathrm{a}_{5.0}+\mathrm{a}_{5.1} \mathrm{FA}+\mathrm{a}_{5.2} \mathrm{LUT}+\mathrm{a}_{5.3} \mathrm{FUR}+\mathrm{a}_{5.4} \mathrm{FSP}+\mathrm{a}_{5.5} \mathrm{SR}+\mu_{6}$

(7) $\mathrm{SHI}=\mathrm{HI}-\mathrm{EH}$

(8) $\mathrm{EH}=\mathrm{EF}+\mathrm{ENF}$

(9) $C R F=a_{6.0}+a_{6.1} P P R+a_{6.2} H I+a_{6.3} Q R+a_{6.4} N H M+\mu 6$

(10) $C R P=a_{7.0}+a_{7.1} P P R+a_{7.2} H I+a_{7.3} Q R+a_{7.4} N H M+\mu_{7}$

Names of the variable in the model are presented in detail in Appendix 1.

A built-model has to meet the criteria of economics, statistics, and econometrics. (Koustoyiannis, 1977). Moreover, the model has to be able to be operated, analyzed, and also producing a conclusion related to the phenomenon being studied (Sitepu and Sinaga, 2006).

Identification result of each structural equation in the model is over identified because variable total of the model is $21(\mathrm{~K}=21)$ consisted of 10 endogenous variables and predetermined variables that all of them are exogenous variable with 11 variables. In the equation with total of $M$ equal to 2 , then it is obtained $(K-M)=19$ greater than $(G-1)=9$. Similarly, in the equations with $6 \mathrm{M}$ is obtained $(\mathrm{K}-\mathrm{M})=15$ greater than 9 . 
Because of all structural equations identified are over identified so that structural equation parameter is analyzed by using Two Stage Least Square (2SLS) methods. It was chosen because having superiority compared to other methods (Gujarati, 2012) the estimation of the model uses a computer application program package named Statistical Analysis System / Econometric Time Series (SAS / ETS) version 9.1 for windows.

\section{RESULTS AND DISCUSSION}

Estimation result of household economics model. Structural equation estimation results presented in Appendix 2 showed that all the equations having R2-value were more than 0.5. $\mathrm{F}$ test results showed that all of the structural equations constructed statistically were significantly different from zero at the one percent level. In terms of economic criteria all parameter estimators of built-model have signs and magnitude which was accordance with the hypothesized. Based on statistical criteria, econometrics, and economic criterion can be concluded that agricultural household economic model built was well enough to use.

The estimation results of agricultural household economic model are presented in Appendix 3 , they were summarized as follows:

(1) $\mathrm{LWH}=-17.0791+0.00033 \mathrm{~W}+0.00267 \mathrm{PQR}-1.4 \mathrm{E}-07 \mathrm{HI}+64.6416 \mathrm{FA}+0.6782 \mathrm{NHM}$

(2) $\mathrm{LOH}=15,8768-0,00047 \mathrm{~W}+60,1199 \mathrm{FA}-0,1952 \mathrm{LWH}+8,38 \mathrm{E}-08 \mathrm{SHI}$

(3) $\mathrm{LUT}=\mathrm{LWH}+\mathrm{LOH}$

(4) FUR $=-0,0517+9,0739(P Q R / P U R)+80,4184 \mathrm{FA}-4,8 \mathrm{E}-07 \mathrm{ENF}$

(5) $\mathrm{FSP}=-0,4222+15,9295(\mathrm{PQR} / \mathrm{PSF})+70,9160 \mathrm{FA}-5,3 \mathrm{E}-07 \mathrm{ENF}$

(6) $\mathrm{OR}=31,7737+1792,834 \mathrm{FA}+6,3033 \mathrm{LUT}+10,8821 \mathrm{FUR}+2,1899 \mathrm{FSP}+5,0437 \mathrm{SR}$

(7). $\mathrm{SHI}=\mathrm{HI}-\mathrm{EH}$

(8) $\mathrm{EH}=\mathrm{EF}+\mathrm{ENF}$

(9) $\mathrm{CRF}=127,197-0,0268 \mathrm{PPR}+3,82 \mathrm{E}-06 \mathrm{HI}+0,2727 \mathrm{OR}+45,8976 \mathrm{NHM}$

(10) $\mathrm{CRP}=200,9859-0,0265 \mathrm{PRP}-1,6 \mathrm{E}-06 \mathrm{HI}-0,0442 \mathrm{QR}+57,3047 \mathrm{NHM}$

The Decision of Labor Use on Rice Farming. In managing rice farming, household not only use labor within the household but also hire wage-labor. Analysis result of labor use was presented in Appendix 3, it showed that agricultural wage variable to have positive significant influence over the use of labor within the households for rice production. Every $1 \%$ increase of agricultural wage would increase $0.7 \%$ of household labor use for rice production. Agricultural wage to have significant influence over the use of wage-labor. Every $1 \%$ increase of agricultural wage caused $2.08 \%$ decrease in the use of household (domestic) labor. This was because households faced limited income so that they would reduce the use of wage labor if there is wage increase.

Variable of seed price to have significant influence over the use of household labor. Every $1 \%$ increase of seed price would encourage households to increase the use of household labor for rice production.

Total of household income has a significant negative sign parameter estimator at the level of 10 percent, it meant the addition of household income total would reduce the use of household labor for rice production. This happenned because households allocated labor to work to earn income and leisure. If the income was considered to have been able to guarantee the household needs, thus the household tended to reduce working time and increase leisure time.

The number of household member to have positive influence over the use of household (domestic) for rice production. The bigger the total of household member, the bigger household (domestic) labor that would be used for rice production activity.

Rice farming area to have positive significant influence over the use of household (domestic) labor or wage-labor for farming rice. The larger rice farming area, the more activities can do, so that it needed many labors. The result was same as reported by Maleha (2008) that farm area cultivated to have positive influence over the use of labor for corps business. 
Parameter estimator of household (domestic) labor $1 \%$ addition would decrease $0.6 \%$ of hired labor used.

Household income surplus to have not real influence but has a positive sign based on hypothesized. It gave an indication that there was a greater tendency that household income surplus would increase the use of hired labor.

The Decision to Use Fertilizer for Rice Production. The analysis result of equation use of urea fertilizer and SP-36 fertilizer presented on appendix 3 showed that ratio variable of seed price to fertilizer to have a significant influence over the use of fertilizer and pesticide. This reflected that farmers were more critical in doing agricultural business because they have considered the price of product and fertilizer although the response was low. It was seen from the elasticity value that less than 1.The rice price getting high would encourage households to add the use of fertilizer, otherwise the increase of fertilizer prices led the decrease of fertilizer use for rice production.

Farming area to have significant influence over the use of fertilizer and pesticide. Every addition of rice farming area led to use of fertilizer become high.

Non-food expenditure showed no significant influence on the use of urea and SP-36 fertilizer, but it has positive parameter estimator that indicated there was a tendency that households would reduce the use of fertilizer along with the increase of non-food expenditure. The results of this study were similar to Leki et al (2016) that non-food expenditures to have not significant influence over the use of fertilizer for maize in Timor. This was one the subsistence household indicators that always gave high priority on the effort to meet food needs from other interests. In addition, households as a member of society could not avoid the traditional events at community which need a lot of costs. To deal with that condition, household was burdened by various demands of tradition/cultural that has to be paid soon. As a result, they would hold household budget reallocation so as to reduce the purchase of fertilizer. For that reason, the use of fertilizer tended to be low.

Several Factors Affecting Rice Production. Analysis results of the rice production behavior presented in Appendix 3 has coefficient of determination of 0.9712 that means 97.92 percent of rice production variation was able to be explained by the explanatory variables included in the model.

Farming rice area to have significant influence over rice production. Every $1 \%$ addition of farming area would increase rice production by $0.4 \%$. Parameter estimator of employment is positive and significant at the level of less than $15 \%$, which means the addition of the use of labor will increase production. This occurred because the addition of labor can be used for weeding, pest control and disease until harvest and post-harvest so that it positively affected rice production.

The use of fertilizer to have significant influence over the rice production, but the use of pesticide to have not significant influence. This result supported the findings of Dwiastuti (2008) and Setiana (2015). Rice seeds did not show significant effect on rice production. Nevertheless, positive parameter estimator sign suggested that there was a tendency that use more seeds will increase the production of rice.

Factors Affecting Rice Consumption's Behavior. In this study, rice consumption's behavior was distinguished by rice consumption derived from farming and rice purchase. The results of parameter estimation rice consumption behavior presented in Appendix 3, shows that the production of rice significantly influences the results of the rice consumption from farming. Every $1 \%$ addition of rice production caused the rice consumption from farming increased up to $0.62 \%$. This phenomenon was related to the purpose of farming to meet household food needs, thus the bigger production, the larger the result got. On the other hand the number of rice production to have negative influence over the rice consumption from purchase. This condition implied that there was quantitative substitution relationship between rice production and rice consumption from the purchase. The higher rice production, the larger the food availability in a household to consumption, so that households will reduce rice consumption from the purchase. 
The number of household to have positive influence over the rice consumption from farming or rice purchase. Thus, the bigger household member, the bigger rice consumption in households.

Total household income to have not significant influence over the rice consumption. Price rice estimator parameter was not statistically different from zero but has a negative value in accordance with the laws of economics. Not real effect of rice price was assumed by the price rice that almost same sold in market. The same result was stated by Taiwon (2006) and Surachman et al. (2009) rice prices did not affect rice demands.

The effect of Policy Simulation. Model validation was first done before simulation by criteria of Theil's Inequality coëficient (U-Theil) and its decomposition (Pindyck and Rubinfied (1991). Based on the average of actual value and the predictions average value presented in Appendix 4, It was apparent that all endogen variables were identified very close between the average of actual value and its prediction. The analysis result showed that all the $U^{\mathrm{M}}$ value was equal to zero, while the $U^{S}$ value close to zero, and $U^{C}$ value approaching one. Thus, it could be concluded that the model was valid and can be used for simulation.

The policy simulation results of farming scale $25 \%$ addition presented in appendix 5 showed that farming expansion resulted in the use of production and labor became high, thereby increased production by $19.84 \%$. Production increases led to household income increased up to $14.86 \%$ and revenue surplus by $29.19 \%$. Production increases encouraged household to increase rice consumption from farming by $14.51 \%$ but decrease rice consumption from purchase by $7.07 \%$.

The policy simulation of subsidy $25 \%$ fertilizer price presented in appendix 5 showed fertilizer price subsidy to have influence over the fertilizer demands through changes in the ration of product price to fertilizer. Structurally, fertilizer use increase to have direct influence over the production and production cost. The impact of fertilizer price subsidy policy affected the use of urea and SP-36 fertilizer increased respectively $12.38 \%$ and $14.87 \%$. There was $4.24 \%$ rice production increase as following effect. Farming production increase caused the availability of food for consumption became high, so that households increased the consumption of rice from farming income but decreased the rice consumption of purchase.

\section{CONCLUSION}

The act of household (domestic) labor use for rice farming is affected by agricultural wage rate, seed price, household income, farming area, and the number of household member. While the use of wage-labor is significant influenced by wage rate, farming area, and the use of household (domestic) labor.

The use of urea and SP-36 fertilizer is influenced by the ratio of seed price to fertilizer and farming area. While the non-food expenditure to have not significant influence. Rice production is significant influenced by farming area, total number of labor used, and amount of fertilizer used.

Rice consumption from farming income is positively influenced by an amount of rice production produced and total of household member. Rice consumption from purchase is negatively influenced by an amount of rice production but positively influenced by the number of household member.

Policy simulation of farming scale extension has a significant impact on labor utilization, production increase, and rice consumption from farming results addition.

\section{POLICY IMPLEMENTATION}

In order to improve the condition of agricultural household economy, thus it needs a government policy to expand farming scale by utilizing the potential of farm area that has not been utilized for a while. This policy needs to be supported by provision of various agricultural supported facilities or agricultural household empowerment program on an ongoing basis. 


\section{APPENDIX 1 - Variable Name}

\begin{tabular}{ll}
\hline Variable & Description \\
\hline \hline LWH & The use of labot within household \\
LOH & The use of labor outside household \\
LUT & The used of total labor \\
FUR & The use of urea fertilizer \\
FSP & The use of SP-36 fertilizer \\
QR & Rice production \\
HI & Household income \\
SIH & Surplus of household income \\
EH & Household expenditure \\
EF & Food expenditure \\
ENF & Non food expenditure \\
RCF & Rice consumption from farming \\
RCP & Rice consumption from purchases \\
PQR & Price of Rice Product \\
PRR & Purchace price of rice \\
PUF & Prices of urea fertilizer \\
PSP & Prices of SP-36 fertilizer \\
FA & Farming area \\
SR & The use of seeds \\
NHM & Number of household member \\
W & Wage \\
\hline
\end{tabular}

APPENDIX 2 - Indicator value R2-Statistic, F-value, Probality F, and Durbin Watson from Structural Equation

\begin{tabular}{|c|c|c|c|c|}
\hline Endegenous variable & R2 & F-value & Pro -F & DW \\
\hline LWWH & 0.97483 & 690.65 & $<<.0001$ & 2.080215 \\
\hline $\mathrm{LOH}$ & 0.89748 & 238.54 & $<.0001$ & 2.229918 \\
\hline FUR & 0.89961 & 328.59 & $<.0001$ & 1.840937 \\
\hline FSP & 0.88994 & 296.48 & $<.0001$ & 1.877879 \\
\hline QR & 0.97917 & 1015.27 & $<.0001$ & 1.757964 \\
\hline CRF & 0.69972 & 63.50 & $<.0001$ & 1.590924 \\
\hline CRP & 0.54212 & 32.26 & $<.0001$ & 1.936612 \\
\hline
\end{tabular}

APPENDIX 3 - Estimation Result of Agricultural Household Economic Model

\begin{tabular}{|c|c|c|c|c|}
\hline Equation & Variable Description & Parameter estimate & t-value & Elasticity \\
\hline LWH & $\begin{array}{l}\text { Intercept } \\
\text { W } \\
\text { PQR } \\
\text { HI } \\
\text { FA } \\
\text { NHM }\end{array}$ & $\begin{array}{l}-17.0791 \\
0.000334 \\
0.002674 \\
-1.4 \mathrm{E}-07 \\
64.64161 \\
0.678161\end{array}$ & $\begin{array}{l}-\left(3.28^{\star * *}\right) \\
\left.2.23^{\star *}\right) \\
\left.8.8^{\star * *}\right) \\
\left.-1.83^{\star}\right) \\
\left.36.8^{* * *}\right) \\
\left.2.1^{* *}\right)\end{array}$ & $\begin{array}{l}0.7031 \\
0.2774 \\
-0.0410 \\
0.7385 \\
0.1888\end{array}$ \\
\hline $\mathrm{LOH}$ & $\begin{array}{l}\text { Intercept } \\
\text { W } \\
\text { FA } \\
\text { LWH } \\
\text { SHI }\end{array}$ & $\begin{array}{l}15.87677 \\
-0.00047 \\
60.11997 \\
-0.19522 \\
8.38 \mathrm{E}-08\end{array}$ & $\begin{array}{l}\left.2.51^{\star *}\right) \\
\left.-2.51^{* *}\right) \\
\left.8.43^{\star * *}\right) \\
\left.-1.99^{\star *}\right) \\
0.78\end{array}$ & $\begin{array}{l}-2.0786 \\
1.4430 \\
-0.4102 \\
0.0689\end{array}$ \\
\hline FUR & $\begin{array}{l}\text { Intercept } \\
\text { PQR/PUR } \\
\text { FA } \\
\text { ENF }\end{array}$ & $\begin{array}{l}-0.05173 \\
9.073995 \\
80.41841 \\
-4.8 \mathrm{E}-07 \\
\end{array}$ & $\begin{array}{l}-0.02 \\
\left.6.61^{\star \star \star}\right) \\
\left.19.77^{\star \star \star}\right) \\
-0.72 \\
\end{array}$ & $\begin{array}{l}0.3713 \\
0.7048 \\
-0.0739\end{array}$ \\
\hline OB & $\begin{array}{l}\text { Intercept } \\
\text { PQR/PSP } \\
\text { FA } \\
\text { ENF }\end{array}$ & $\begin{array}{l}-0.42219 \\
15.92948 \\
70.91602 \\
-5.3 E-07\end{array}$ & $\begin{array}{l}-0.18 \\
\left.7.38^{\star * \star}\right) \\
\left.16.72^{\star * \star}\right) \\
-0.8\end{array}$ & $\begin{array}{c}0.4461 \\
0.6612 \\
-0.0869\end{array}$ \\
\hline QR & $\begin{array}{l}\text { Intercept } \\
\text { FA } \\
\text { LUT } \\
\text { FUR } \\
\text { FSP } \\
\text { SR } \\
\end{array}$ & $\begin{array}{l}31.77372 \\
1792.834 \\
6.303262 \\
10.8821 \\
2.189868 \\
5.043663\end{array}$ & $\begin{array}{l}1.23 \\
\left.4.19^{\star * *}\right) \\
\left.1.54^{\star}\right) \\
\left.4.83^{\star * *}\right) \\
0.99 \\
0.86\end{array}$ & $\begin{array}{l}0.4039 \\
0.1835 \\
0.2798 \\
0.0529 \\
0.0425\end{array}$ \\
\hline RCF & $\begin{array}{l}\text { Intercept } \\
\text { PPR } \\
\text { HI } \\
\text { QR } \\
\text { NHM }\end{array}$ & $\begin{array}{l}127.197 \\
-0.02684 \\
3.82 \mathrm{E}-06 \\
0.272664 \\
45.89757\end{array}$ & $\begin{array}{l}0.14 \\
-0.3 \\
0.9 \\
\left.11.4^{\star \star *}\right) \\
\left.1.92^{\star *}\right)\end{array}$ & $\begin{array}{l}-0.6790 \\
0.0511 \\
0.6173 \\
0.5707\end{array}$ \\
\hline
\end{tabular}


Continue of Appendix 3

\begin{tabular}{lllll}
\hline RCP & Intercept & 200.9859 & 0.67 & -1.6231 \\
& PPR & -0.0265 & -0.9 & -0.0514 \\
HI & $-1.6 \mathrm{E}-06$ & -1.11 & -0.2425 \\
& QR & -0.04423 & $\left.-5.53^{* * *}\right)$ & 1.7252 \\
\hline
\end{tabular}

APPENDIX 4 - Actual Average Value and Prediction. U-Theil Coefficient and its Decomposition in Agricultural Household Economic Model

\begin{tabular}{|c|c|c|c|c|c|c|c|}
\hline Variable & $\begin{array}{l}\text { Actual } \\
\text { Average } \\
\text { Value }\end{array}$ & $\begin{array}{l}\text { Prediction } \\
\text { Average } \\
\text { Value }\end{array}$ & Deviation & $\left(U^{M}\right)$ & $\left(U^{S}\right)$ & $\left(\mathrm{U}^{\mathrm{C}}\right)$ & $\begin{array}{l}\text { Coefficient } \\
\text { U-Theil }\end{array}$ \\
\hline 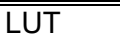 & 24.7807 & 24.8837 & 0.416 & 0.0000 & 0.0000 & 1.0000 & 0.0655 \\
\hline LWH & 16.7895 & 16.8271 & 0.224 & 0.0000 & 0.0000 & 1.0000 & 0.0717 \\
\hline $\mathrm{LOH}$ & 7.9912 & 8.0567 & 0.820 & 0.0000 & 0.0300 & 0.9700 & 0.1542 \\
\hline FUR & 21.886 & 21.8859 & 0.000 & 0.0000 & 0.0300 & 0.9700 & 0.1424 \\
\hline FSP & 20.5702 & 20.5708 & 0.003 & 0.0000 & 0.0300 & 0.9700 & 0.1500 \\
\hline QR & 851.3 & 852 & 0.082 & 0.0000 & 0.0100 & 0.9900 & 0.0780 \\
\hline SHI & 6565501 & 6466099 & -1.514 & 0.0000 & 0.0700 & 0.9300 & 0.2407 \\
\hline $\mathrm{EH}$ & 8458351 & 8376657 & -0.966 & 0.0000 & 0.0500 & 0.9500 & 0.1014 \\
\hline CRF & 376 & 375.5 & -0.133 & 0.0000 & 0.1000 & 0.9000 & 0.2565 \\
\hline CRP & 155.3 & 155.6 & 0.193 & 0.0000 & 0.1400 & 0.8600 & 0.2521 \\
\hline
\end{tabular}

Appendix 5 - Policy Simulation Effect of Farming Scale 25\% Extension and 25\% Subsidy of Fertilizer Price

\begin{tabular}{llll}
\hline Variable & SIM BASIC & $25 \%$ Extension Policy of Farming Scale & $25 \%$ Subsidy Policy of Fertilizer Price \\
\hline \hline LUT & 24.8837 & 21.451 & -0.013 \\
LWH & 16.8271 & 16.955 & -0.137 \\
LOH & 8.0567 & 30.839 & 0.245 \\
FUR & 21.8859 & 17.623 & 12.377 \\
FSP & 20.5708 & 16.534 & 14.868 \\
QR & 852 & 19.836 & 4.237 \\
HI & 14842756 & 14.865 & 1.390 \\
SHI & 6466099 & 29.185 & 2.815 \\
EH & 8376657 & 3.811 & 0.291 \\
CRF & 375.5 & 14.514 & 2.850 \\
CRP & 155.6 & -7.069 & -1.285 \\
\hline
\end{tabular}

\section{REFERENCES}

1. Barnum H.N., and L. Squire. (1979). A Model of an Agricultural Houshold. Theory and Evidence, Published for the World Bank, The Johns Hopkins University Press. Baltimore and London.

2. Becker, G. S. (1965). The Economic Approach to Human Behavior. The University of Chicago Press, Chicago.

3. Bokhuseva, R. and H. Hockmann. (2004). Output Volatility in Russian Agriculture: The Significance of Risk and Inefficiency. Working Paper. Institute of Agricultural Development in Central and Eastern Europe (IOMA), Halle.

4. BPS. (2011). Kajian Konsumsi dan Cadangan Beras Nasional 2011. Statistic Center Indonesia, Jakarta

5. BPS. (2013). Hasil Sensus Pertanian 2013 (Pencacahan Lengkap). . Statistic Center Indonesia, Jakarta

6. Chang, Y. M., B. W. Huang and Y. J. Chen. (2012). Labor Supply, Income, and Welfare of the Farm Household. Labor Economics 19 (2012), 427-437.

7. Dwiastuti, R. (2008). Skenario Kebijakan Diversifikasi Konsumsi Pangan Berbasis Perilaku Rumahtangga dan Kelembagaan Lokal. Kerjasama Badan Penelitian dan Pengembangan Depertemen Pertanian dengan Lembaga Penelitian dan Pengabdian Masyarakat Universitas Brawijaya. Malang.

8. Ellis F. (1988). Peasant Economics: Farm Hiusholds and Agrarian Develompment Analysis. Fifth Edition. Jhon Wiley and Sons Inc., New York. 
9. Fariyanti, A., S. Kuntjoro, Hartoyo, and A. Daryanto. (2007). Perilaku Ekonomi Rumahtangga Petani Sayuran Pada Kondisi Resiko Produksi dan Harga Di Kecamatan Pangelanggan Kabupaten Bandung. Jurnal Agro Ekonomi 25(2), 178 - 206.

10. Gujarati, D. (2012). Dasar-dasar Ekonomterika. Buku 2. Jakarta.

11. Hanani, N. and Yonekura. (2009). Economic Decision Making of Vegetable Peasant Household. http://nuhfil.lecture.ub.ac.id /.../jepang-jurnal-nuhfil.pdf.

12. Ilsan, M. (2015). Ketahanan Pangan Rumahtangga Petani pada Tiga Tipe Agroekosistem di Sulawesi Selatan. PhD Thesis. Program of Agriculture, Interest: Agriculture Economy, University of Brawijaya, Malang.

13. Irawam. (2005). National Rice Availability Analysis A Simulation Study of Dynamic System Approach. Proceeding of Agriculture Multifunction, 111-130. balittanah.litbang. pertanian.go.id/ind/dokumentasi/.../mflp2005/irawan_dinamis.pdf.

14. Kementerian Perdagangan. (2013). Kajian Peran Kebijakan Perdagangan Dalam Rangka Percepatan Swasembada Pangan. Pusat Kebijakan Perdagangan Dalam Negeri. Badan Pengkajian dan Pengembangan Kebijakan Perdagangan. Ministry of Trade Republic of Indonesia, Jakarta.

15. Koutsoyiannis, A. (1987). Theory of Econometrics. An Introductory Exposition of Econometric Methods. Second Edition. ELBS. Macmillan Education, Ltd., London.

16. Kumbhakar, C.S. (2002). Specification and Estimation of Production Risk, Preferences and Technical Efficiency. American Journal Agricultural Economic. 84(1), 8-22.

17. Leki S., N. Hanani, R. Dwiastuti, B. Setiawan. (2016). Household Economic Decisions of Corn Farmers at West Timor, Indonesia. Current Agriculture Research Journal. 4 (1) June 2016: 74-83.

18. Leki, S. (2010). Kajian Kebijakan Pertanian Dalam Memenuhi Kebutuhan Dasar Penduduk Di Nusa Tenggara Timur. Perkumpulan Pikul. Kupang. www.perkumpulanpikul.or.id

19. Makki, M. F. (2014). Perilaku Ekonomi Rumahtangga Petani Padi di Lahan Rawa Lebak Kabupaten Hulu Sungai Utara Kalimantan Selatan. PhD Thesis. Faculty of Agriculture, University of Brawijaya, Malang.

20. Maleha. (2008). Perilaku Rumahtangga Petani Dalam Pencapaian Ketahanan Pangan. PhD Thesis. Graduate Program, University of Brawijaya, Malang.

21. Nurasa, T dan A. Purwoto. (2012). Profitability Analysis On Irrigated Rice Farming In Java and The Outer Islands Within The Patanas Rurality. pse.litbang.pertanian.go.id/ind/ pdffiles/Pros_2012_03C_MP_TjetjepADP.pdf.

22. Pindyck R.S., and D.L. Rubinfeld. (1991). Econometric Models and Economic Forecasts. McGraw Hill, USA.

23. Rochani, S. and E. M. Lolollo. (2005). Faktor-faktor yang Mempengaruhi Keputusan Ekonomi Rumahtangga Petani Di Kelurahan Setugede Kota Bogor. Jurnal Agro Ekonomi, 23(2), $133-158$.

24. Setiani. (2015). Produksi Padi Dan Jagung Dalam Ekonomi Rumah Tangga Petani Lahan Sawah: Model Dan Simulasi Kebijakan (Studi Kasus Di Desa Kepuh Kembeng Kecamatan Peterongan Kabupaten Jombang). Media Trend. 10(2), 104-115.

25. Singh I., I.Square and J. Strauss. (1986). Basic Model. Theory Empirical Result and Policy Conclusions. In Sigh. I., L. Square and J. Strauss (Eds). Agricuktural Houshold Models Extenssions, Applications dan Policy, The Johns Hopkins University Press, Baltimore and London, 17-42

26. Sitepu, R. K. and B. M. Sinaga. (2006). Apliasi Model Ekonometrika. Estimasi, Simulasi dan Peramalan Menggunakan Program SAS. Program Study of Agriculture Economy, Graduate School of Bogor Agricultural University, Bogor.

27. Surachman H., et al. (2009). Kajian Pengembangan Model Proyeksi Jangka Pendek Pasar Komoditas Pangan Pokok, Pusat Penelitian dan Pengembangan Perdagangan dalam Negeri Badan Penelitian dan Pengembangan Perdagangan. Ministry of Trade Republic of Indonesia. Jakarta.

28. Taiwon, H. (2006). Analisis Ketahanan Pangan Utama Indonesia Pada Era Liberalisasi Perdagangan. PhD Thesis. Faculty of Agriculture, University of Brawijaya, Malang. 